\title{
Efficiency of selection probes in vegetable growing
}

V. Kravchenko,

Academician of the National Academy of Sciences of Ukraine, Doctor of Agricultural Sciences National Academy of Agrarian Sciences of Ukraine

\section{S. Korniyenko,} doctor of agricultural sciences

T. Gorova,

Academician of the NAAS, Doctor of Agricultural Sciences

O. Khareba,

L. Teriokhina

\section{Candidates of Agricultural Sciences}

Institute of Vegetable and Melons, NAAS

The purpose. To study efficiency of selection processes in vegetable growing. Methods. Laboratoryanalytical, experimentally-field, statistical. Results. Data are generalized of selection probes in vegetable growing for the season of $2011-2015$. Efficiency of selection is shown. Characteristics of the best cultivars and hybrids of vegetable crops are given. Instances of rising of efficiency of selection process are brought. Conclusions. For a five-year period 56 cultivars and hybrids of vegetable crops with high productivity and quality, stable against action of stressful factors are created and recommended for growing in Ukraine. Efficiency of application of new methods of selection is shown.

Key words: selection, attributes, cultivar, hybrid, methods, genetics bank, strain testing.

Vegetable crops can be fully entitled to be call the third bread of the population. Vegetable products are diverse: root crops, stems, leaves and flowers, fruits, which usually have dietary, protective and therapeutic properties. Vegetables contain a significant amount of vitally important substances for humans - vitamins, essential acids, minerals, trace elements. According to medical standards, a person needs to consume $161 \mathrm{~kg}$ of vegetable and melon products per year.

The grade and the hybrid are the basis of any technology. The complex of their characteristics depends on yield, quality, ecological purity, energy efficiency of production. Therefore, it is important to evaluate the effectiveness of Ukrainian selection of vegetable crops, to show its achievements, to recommend the production of better varieties and hybrids.

The purpose of the research is to analyze the selection approaches and their results regarding the efficiency of breeding processes with vegetable crops.

Materials of the research. Already analyzed the efficiency of breeding research on the major vegetable crops for 2011-2015. For breeding research, of the Institute of Vegetable and Melons growing of NAAS, the world collection of vegetable and melon crops, genotypes of new varieties and hybrids created the source material.

Breeding studies were carry out using well-known techniques [1-10]. The evaluation of these varieties and hybrids was carry out using the methods of the State variety test [11]. Mathematical processing of experimental data for B.O. Dospekhov [12]. 
1. The number of varieties and hybrids that were transfers to the state variety inspection and entered in the State Register (2011 - 2015)

\begin{tabular}{|c|c|c|c|c|c|c|}
\hline \multirow[t]{2}{*}{ Institution } & \multicolumn{3}{|c|}{ Transferred to state variety testing } & \multicolumn{3}{|c|}{$\begin{array}{c}\text { Listed in the State Register of } \\
\text { Plant Varieties }\end{array}$} \\
\hline & $2011-2014$ & 2015 & Total & $2011-2014$ & 2015 & Total \\
\hline $\begin{array}{l}\text { Institute of Vegetable and } \\
\text { Melons growing of NAAS }\end{array}$ & 11 & 18 & 29 & 16 & 11 & 27 \\
\hline Dnipropetrovsk RS & 3 & 4 & 7 & 3 & 4 & 7 \\
\hline Donetsk RS & 3 & 0 & 3 & 6 & 0 & 6 \\
\hline "Mayak" RC & 11 & 6 & 17 & 5 & 4 & 9 \\
\hline Total & 28 & 28 & 56 & 30 & 19 & 49 \\
\hline
\end{tabular}

The results of the researchers. In 2015, under the vegetable crops, 447 thousand hectares were occupy in the open ground of Ukraine. At the yield of $206.1 \mathrm{ts} / \mathrm{ha}$, the gross harvest of vegetable crops amounted to 9210.8 ths. tons. The farms produced $86 \%$ of the gross crop for yields of $192.6 \mathrm{cwt} / \mathrm{ha}$ and $14 \%$ for agricultural holdings with a yield of $363.9 \mathrm{cwt} / \mathrm{ha}$.

Recent studies in the selection of vegetables were aim at developing methodological approaches to modifying breeding schemes for the creation of new genotypes based on modern methods of genetics, molecular biology, immunity [8-10]. Climate change adapted selection for adaptability, resistance to stress factors, ability to form complex of desirable features in complex conditions of ontogenesis [7].

A significant source of useful features is the genetic bank of the world collection, which in the institute system has 4825 samples of 73 botanical species from 70 countries of the world. Over the past years, 742 collections have used in the selection process of vegetable crops. Particularly valuable breeding material ware obtained for remote hybridization of tomato, sweet pepper, eggplant.

In cattle and pumpkins, phenotypic marker signs of the type of growth, color of the leaf, stem, fetus and others are widely used $[4,6]$.

In the selection of immunity, artificial provocative infectious backgrounds were actively use in vivo and in vitro. In this way, established cell lines of tomato, sweet pepper, eggplant resistant to fungal diseases (resistance 7-8 points) [8].

In the State Register of Plant Varieties, suitable for distribution in Ukraine, there are 266 varieties and 31 hybrids of vegetable, melon and infrequent plant breeds of the institute and coordinated institutions. Representing $45 \%$ of the total (665) registered varieties and hybrids. The qualification examination 56 ware transferred and 49 varieties and hybrids ware entered in the State Register of plant varieties in 2011-2015 (Table 1).

In recent years, the breeding program has already adjusted to create highly tolerant varieties and hybrids of vegetable and melon crops.

The efficiency of complex application of experimental mutagenesis and culture of tissues in vitro for heterozygous tomato selection has already proved [7].

The in vitro cell selection method has created lines of vegetable plants that are sources of resistance to diseases, carriers of sterility genes, early gastricity and high content of valuable biochemical components [4-6].

Because of the selection of stable genotypes of vegetable plants, five varieties of tomatoes for protected soil (polyester greenhouses) with high resistance to fusarium fading, with different coloring of the fetus: Rosa, Rozhevyyi veleten, Rozheve sertse, Budda, Gurman and hybrid of tomato Anyuta $F_{1}$ were already out to the most widespread diseases (Table 2).

For open soil conditions, the tomatoes of the salad line Seven and the Odeskyyi salatnyyi (the Institute of Agriculture of the Black Sea Coast of the NAAS) with the yield of 54-64 tons/ha. They are resistant to 
alternaria (5 points) and suitable for mechanized harvesting; Geyiser and Yuvileyinyyi with a yield of 77$80 \mathrm{t} / \mathrm{ha}$, dry matter content of $5.3-5.9 \%$ (Institute of irrigation agriculture of NAAS).

Already, new varieties of sweet pepper - Lyubasha with a period from the stairs to technical maturity 95 days, yields 42 t/ha. Heat-resistant Zvenigora with a yield of 56-66 t/ha and eggplant varieties Nasoloda with a yield of 75-80 t/ha and Veronik. Its fruit ware reached on the 110th day (Southern State Agricultural Experimental Station of the Institute of Water Problems and Land Reclamation of NAAS).

\section{Economically valuable signs of new varieties and hybrids of tomatoes for protected soil (polyester greenhouses, average for 2013-2015)}

\begin{tabular}{|c|c|c|c|c|c|c|c|}
\hline \multirow[b]{2}{*}{ Variety/hybrid } & \multirow[b]{2}{*}{$\begin{array}{l}\text { The yields, } \\
\mathrm{kg} / \mathrm{m}^{2}\end{array}$} & \multirow[b]{2}{*}{$\begin{array}{l}\text { Weight } \\
\text { of fruit, } \\
\text { g }\end{array}$} & \multirow[b]{2}{*}{$\begin{array}{l}\text { Period stairs } \\
\text { - ripening, } \\
\text { days }\end{array}$} & \multirow[b]{2}{*}{$\begin{array}{c}\text { Resistance } \\
\text { to disease, } \\
\text { mark }\end{array}$} & \multicolumn{3}{|c|}{ The contents } \\
\hline & & & & & $\begin{array}{c}\text { Dry } \\
\text { matter, \% }\end{array}$ & $\underset{\%}{\text { Sugars, }}$ & $\begin{array}{c}\text { Vitamin } \\
\mathrm{C}, \\
\mathrm{mg} / 100 \\
\mathrm{~g}\end{array}$ \\
\hline $\begin{array}{l}\text { KDS-5 } \\
\text { standard }\end{array}$ & 17,1 & 130 & 105 & 6 & 5,2 & 3,82 & 22,6 \\
\hline $\begin{array}{l}\text { Rozhevyyi } \\
\text { veleten }\end{array}$ & 18,6 & 250 & 109 & 7 & 4,7 & 3,20 & 20,80 \\
\hline $\begin{array}{l}\text { Rozheve } \\
\text { sertse }\end{array}$ & 18,0 & 200 & 116 & 7 & 4,8 & 3,5 & 24,82 \\
\hline Gurman & 13,7 & 68 & 110 & 7 & 5,1 & 3,88 & 18,76 \\
\hline Budda & 14,8 & 158 & 106 & 7 & 5,1 & 3,72 & 18,56 \\
\hline Rosa & 13,0 & 200 & 113 & 7 & 5,6 & 4,2 & 23,40 \\
\hline Anyuta $F_{1}$ & 19,4 & 123 & 105 & 7 & 5,0 & 3,76 & 24,60 \\
\hline $\mathrm{SSD}_{05}, \mathrm{t} / \mathrm{ha}$ & $0,7-0,9$ & & & & & & \\
\hline
\end{tabular}

The selections of genotypes with female flowering have made by cabbage shortbreads hybrid Kasatik $F_{1}$, short-lived parthenocarpic Nadiya $F_{1}$. It is resistant to root rot. Hybrid Kamila $F_{1}$ is a bouquet arrangement of female flowers (2-5 in the knot).

In the selection of cabbage and onion plant species, the technique of creating an artificial infectious background and the method of selecting a stable source material of cabbage because of individual resistance to fusarium fading has already worked out. Created lines of white cabbage K-13203 and K13125, savoy Azhur and reddish Polina.

With the use of the polycrose method, a new variety of willow-beetroot Granat with a yield of onion 21 $\mathrm{t} / \mathrm{ha}$, green onion - $44 \mathrm{t} / \mathrm{ha}$, already preservation of $92 \%$ were introduce. The bulbs contained 19.7 dry matter, $12.3 \%$ total sugar, $35.3 \mathrm{mg} / 100 \mathrm{~g}$ of vitamin $\mathrm{C}$ in green leaves.

For the northern zone Polissya conditions established early ripening varieties of onion Balada with a high dry matter content - 16.6\%, Vitamin C - $10.5 \mathrm{mg} / 100 \mathrm{~g}$, yield $37 \mathrm{t} / \mathrm{ha}$, survival - 95\% (Nosivska breeding and research station of Myronivka Institute of Wheat named after V.M. Remesla).

The high quality Zagrava willow has already been introduced with a vegetation period of 79 days, a green feather yield of $17.3 \mathrm{t} / \mathrm{ha}$, and mature onion - $6.9 \mathrm{t} / \mathrm{ha}$. Onion-schnapps Lastivka with a yield of green leaves $-41.4 \mathrm{t} / \mathrm{ha}$, with the content of vitamin C $-14.8 \mathrm{mg} / 100 \mathrm{~g}$ ("Mayak" RS of IVM of NAAS).

Particular attention deserves the creation of root crops and abundant vegetable plants rich in anthocyanins: carrots ( $\beta$-carotene), beet table (betanin), pine-aromatic (efironous), lettuce (lactoxin).

By modification of the selection schemes and intrinsic hybridization, a new variety of table beet Yulis with a vegetative period of 95-100 days and a yield of 57-59 t/ha was obtained.

The selection process was already accelerated twice during the creation of the lines of beet Desert, Betaninchik, Kolobok and hybrid Raund $F_{1}$ with a yield of $86 \mathrm{t} /$ ha, dry matter content $-14,1 \%$, total sugar $10,77 \%$, vitamin C - 9, $75 \mathrm{mg} / 100 \mathrm{~g}$, betanine - $382.8 \mathrm{mg} / 100 \mathrm{~g}$ (Table 3). 
3. Economically valuable signs of new hybrids of table beet (average per 2013-2015)

\begin{tabular}{|l|c|c|c|c|c|}
\hline \multicolumn{1}{|c|}{ Signs } & Goryzont $\mathrm{F}_{1}$ & Merydian $\mathrm{F}_{1}$ & Konus $\mathrm{F}_{1}$ & Raund $\mathrm{F}_{1}$ & $\begin{array}{c}\text { Bordo kharkivskyyi, } \\
\text { standard }\end{array}$ \\
\hline Total yields, $\mathrm{t} / \mathrm{ha}$ & & & & & \\
\hline Marketability, \% & 62,3 & 41,2 & 49,7 & 86,4 & 36,7 \\
\hline Weight of root, $g$ & 95,0 & 91,0 & 91,0 & 92,4 & 87,0 \\
\hline Content: & & 465,0 & 342,0 & 376,0 & 264,0 \\
\hline dry matter, \% & 20,8 & 18,7 & 21,12 & 14,1 & 16,9 \\
\hline sugars, \% & 11,02 & 12,7 & 13,56 & 10,77 & 11,8 \\
\hline vitamin C, $\mathrm{mg} / 100 \mathrm{~g}$ & 7,02 & 9,5 & 8,08 & 9,75 & 8,7 \\
\hline betanin, $\mathrm{mg} / 100 \mathrm{~g}$ & 381,40 & 561,0 & 375,3 & 382,8 & 296,9 \\
\hline SSD $05 \mathrm{t} / \mathrm{ha}$ & $3,1-4,2$ & & & & \\
\hline
\end{tabular}

Initial parent lines have already created and a scheme for obtaining hybrids of the table beet $F_{1}$ mixer single- and multi-seeded based on the Cytoplasmic male sterility (CMS). What contributed to the creation of new hybrids of the table beet Goryzont $F_{1}$ with a yield of 55-70 $t /$ ha, with a content of betanine 381 $\mathrm{mg} / 100 \mathrm{~g}$. A new hybrid Meridian $\mathrm{F}_{1}$ with a yield of $41.2 \mathrm{t} / \mathrm{ha}$, a botanin content of $561 \mathrm{mg} / 100 \mathrm{~g}$. Hybrid Konus $F_{1}$ with a yield of $49.7 \mathrm{t} / \mathrm{ha}$, and a betanin content of $375 \mathrm{mg} / 100 \mathrm{~g}$ (see Table 3).

A high-adaptive early-grated carrot variety Midas of sort types Shantene has been created, with a vegetative period of 80 days, a yield of $52 \mathrm{t} / \mathrm{ha}$, and a high level of resistance to disease at a rate of 7 points. On a sterile basis, the medium-term heterozytic hybrid Terazh $3 F_{1}$ (Skvyrska RS of organic production) with a vegetative period of 130 days, with a total yield of $60 \mathrm{t} / \mathrm{ha}$, with a content of betacarotene $19.5 \mathrm{mg} / 100 \mathrm{~g}$ (tab. 4).

4. Economically valuable signs of varieties of carrot Midas and hybrids Terazh $3 F_{1}$ (average for 2013-2015)

\begin{tabular}{|l|c|c|c|c|}
\hline \multicolumn{1}{|c|}{ Variety, hybrid } & Yields, t/ha & $\begin{array}{c}\text { Marketability, } \\
\%\end{array}$ & Weight of rot, g & $\begin{array}{c}\text { Resistance to } \\
\text { diseases, } \\
\text { mark }\end{array}$ \\
\hline Shantane skvyrska, standard & 45,5 & 75,8 & 75 & 5 \\
\hline Midas & 52,0 & 88,9 & 121 & 7 \\
\hline Skvyryanka $\mathrm{F}_{1}$, standard & 51,7 & 74,7 & 104 & 7 \\
\hline Terazh 3 F & 57,1 & 84,2 & 111 & 7 \\
\hline SSD $_{05}$ t/ha & $3,1-3,3$ & & & \\
\hline
\end{tabular}

According to the results of the selection of the infrequent crops, a new variety Zhyvchik with a shortened cone-shaped root crop ware created. It is suitable for mechanized harvesting, high tidiness. The hybrid of celery root crop Spartanets $F_{1}$ with a yield of root crops of $23 \mathrm{t} / \mathrm{ha}$, dry matter content $9.6 \%$, total sugar $5.4 \%$, vitamin C $6.94 \mathrm{mg} / 100 \mathrm{~g}$ (RS "Mayak", IVM of NAAS).

The method of induced mutagenesis has created 3 varieties of lettuce Krutyanskyyi, Patriot and Mazhor (RS "Mayak", IVM of NAAS). The varieties have a yield of 9.3-9.8 t/ha, vitamin C at a level of 26$36 \mathrm{mg} / 100 \mathrm{~g}$ and a drought tolerance.

In order to expand the range, they created 20 new pine-aromatic genotypes of coriander ginseng, grasshopper medicinal, wormwood, portulaca gardens, mangold, dill, common mint, and fuselage (RS "Mayak", IVM of NAAS and Transcarpathian RSDS of the Institute of Agriculture of the Carpathian region of NAAS) [9]. 
An effective breeding operation was to create varieties of common beans (vegetable and grains) with high protein content. Already the varieties of beans of the usual Gotuka, Dar and Charivnytsya have created. Which are suitable for mechanized harvesting (Transcarpathian RSDS).

The highly adaptive early-hybrid watermelon Kazka $F_{1}$, with a yield of $33.8 \mathrm{t} / \mathrm{ha}$, and an original earlygrape variety of daisies, with a yield of $28.7 \mathrm{t} / \mathrm{ha}$, of white color, golden mint, was created because of the attraction of effective source material (IVM of NAAS).

With the help of the method of choosing goniasis maternity lines for different thickening schemes, a new early-hybrid melon Zagrava with a total yield of $34.4 \mathrm{t} / \mathrm{ha}$, ware obtained using the method of choosing goniasis maternity lines under various thickening schemes. According to the selection of parent components with signs of stability and plasticity, the medium-long hybrids of watermelon Mulat $F_{1}$ (Dnipropetrovsk RS of IVM of NAAS) with a yield of 34.1 t/ha have created.

Using the marketing features, a new seed germinator hybrid was used to use Paradyz $F_{1}$ with a total yield of $51.5 \mathrm{t} / \mathrm{ha}$. Moreover, a hybrid of the large-fruited of pumpkin Korol $\mathrm{F}_{1}$ variety of winter, which yields by $31-84 \%$, prevails in the standards. The method of induced mutagenesis was created by the ultra-fast hybrid heterozygous Otaman $F_{1}$ hybrid with a yield of $34 \mathrm{t} /$ ha (Dnipropetrovsk RS, IVM of NAAS).

\section{Conclusions}

With the use of theoretical, methodological and practical developments in genetics, biotechnology, immunity and the use of quality indicators of the world gene pool, they have created competitive varieties and hybrids of vegetable and melon crops.

Effective use of new varieties and hybrids has already confirmed by high yields, product quality, resistance to diseases and stress factors, storage and processing ability.

\section{Bibliography}

1. Metodicheskie ukazaniya po selektsii sortov I gibridov tomata dlya otkrytogo I zakrytogo grunta. 1986. $-112 \mathrm{~s}$.

2. Suchasni metody selektsii ovochevykh i bashtannykh kultur: za red. T. K. Gorovoi. - Kh. : Osnova, 2001. $-641 \mathrm{~s}$.

3. Metodyka doslidnoi spravy $v$ ovochivnytstvi I bashtannytstvi; za red. G.L. Bondarenka, K. I. Yakovenka. - Kh. : Osnova, 2001. - 644 s.

4. Boswell V. R. Impovement and genetics of tomatoes peppers and eggplant/V. R. Boswell. - 1987. 176-206.

5. Shipriss C. A new male sterility gene in Capsicum annuum I.J./C. Shipriss, R. Firankel//Amer.doc. Hort. Sci. - 1969. - 94. - P. 385-387.

6. Yuan J. Study of foral opgan morphology and inheritance of a new functional male steribe peper line/J. Yuan, S. Li//Hereditas. - 2000. - 22. - P. 28-30.

7. Selektsiya ovochevykh roslyn: teoriya I praktyka/V. A. Kravchenko, Z.D. Sych, S. I. Kornienko ta in. - K. : NUBIP. - 2013. - $362 \mathrm{~s}$.

8. Netraditsionnye metody selektsii ovoshchnykh I bakhchevykh rasteniyi; pod red. A. P. Samovola. K. : agrar. nauka, 2014. - $96 \mathrm{~s}$.

9. Wehner T. C. Vene Listfor Cocumbers/T. C. Wehner, J. E. Stamb//Cucurbim Yenet. Crop. Rpt. 1997. - V. 20. - P. 66-88.

10. Osoblyvosti tekhnologii vyroshchyuvannya maloposhyrenykh ovochevykh roslyn monografiya/S. I. Kornienko, V.V. Khareba, O.V. Khareba, O. V. Poznyak. - Vinnytsya, 2015. - $133 \mathrm{~s}$.

11. Metodyka derzhavnogo sortovyprobuvannya silskogospodarskykh kultur (kartoplya, ovochevi ta bashtanni kultury). - K., 2001. - $102 \mathrm{~s}$.

12. Dospekhov B. A. Metodika opytnogo dela/B. A. Dospekhov. - M. : Agropromizdat, 1985. - $351 \mathrm{~s}$. 